\title{
Oviposition niches and behavior of the genus Lixus Fabricius (Coleoptera: Curculionidae, Lixinae)
}

\section{Levent Gültekin}

\begin{abstract}
Gültekin, L. 2007: Oviposition niches and behavior of the genus Lixus Fabricius (Coleoptera: Curculionidae, Lixinae). — Entomol. Fennica 18: 74-81.

Oviposition places in the host plants of 23 Lixus Fabricius species in eastern Turkey were identified. Lixus nordmanni Hochhuth, L. subtilis Boheman, L. incanescens Boheman, L. brevipes Brisout, L. sp. n. pr. brevipes Brisout, L. ochraceus Boheman, L. furcatus Olivier, L. rubicundus Zoubkoff, L. angustatus (Fabricius), L. punctiventris Boheman, L. fasciculatus Boheman, L. bardanae (Fabricius), L. sp. n. pr. korbi Petri, and L. scolopax Boheman deposited eggs in the main stem. Lixus filiformis (Fabricius), L. cardui Olivier, and L. korbi Petri oviposited in the main stem and lateral branch of their host plants. L. circumcinctus Boheman laid eggs on both stem and petiole, whereas L. siculus Boheman, L. farinifer Reitter, L. cylindrus (Fabricius), and L. sp. n. pr. furcatus Olivier used the petioles, a new ecological niche for the genus Lixus. The unique species $L$. obesus Petri selected the seed capsule for laying eggs and completing its generation.
\end{abstract}

Levent Gültekin, Atatürk University, Faculty of Agriculture, Plant Protection Department, 25240,Erzurum-Turkey;E-mail:lgul@atauni.edu.tr

Received 24 March 2005, accepted 29 August 2006

\section{Introduction}

The superfamily Curculionoidea, which contains more than 50,000 described species, is the richest organisms known (O’Brien \& Wibmer 1978). This diversity is hypothesized to result from invasion of the adaptive zone of strict phytophagy (Anderson 1995). The use of the rostrum in preparing an oviposition site is considered a key adaptation that facilitates entry by circumventing recognized evolutionary barriers to plant feeding and permits the use of a broad spectrum of plant parts as food sources (Anderson 1995). Some structural niches of plants represent a consistent and predictable resource gradient, ranging from the thick stem at the base of the plant to the thin stems at the tip. Hence, for stem-inhabiting spe- cies, size constraint could play an important role in oviposition and larval development (Eber et al. 1999). A study of the different species of endophagous stem borers on thistles showed niche partitioning according to body size (Zwölfer \& Brandl 1989). Hence, two or even three different species coexist in different parts of the stem of the same host plant.

The genus Lixus has a nearly worldwide distribution and comprises more than 500 species; in the Palaearctic region, more than 150 species are found (Petri 1904/1905, Csiki 1934, Ter-Minassian 1967). Zwölfer \& Harris (1984) indicated that genus of the Lixus, with long and slender larvae, pupae, and adults is so adapted to mine the stems of herbaceous plants, although a few species attack the roots and buds. The female rostrum 
is long, curved, and shaped in such a way that eggs are placed in the interior of the herbaceous stem. Species of Lixus has been to a broad spectrum of plant families that provide suitable oviposition sites. Korotyaev \& Gültekin (2003) stated that the host range includes several families of higher plants. Majority of the comparatively well-known species develop or at least feed on species of several genera of a single plant family. With some plant families - the Chenopodiaceae, Brassicaceae, and Apiaceae - species of more than one subgenus of Lixus are associated. It is not always clear if this reflects a multiple transition of the genus to plants of these families or a broad diversification of the phyletic lineages associated with the respective plant families.

Some of the Lixus species are actual (Şengonca 1981) or potential pests of agriculture (Volovnik 1988, Nikulina 1989, Y1ldırım \& Özbek 1992), but some have potential uses in the biological control of weeds (Julien et al. 1984, Freese 1994, Briese 1996, Sobhian et al. 1999, Gültekin et al. 2000, 2004, Gültekin 2004). There are only two special studies about oviposition niches of the genus Lixus. Volovnik (1994) describes the oviposition places and behavior of eight Lixus species in Ukraine. Gültekin (2005) reports that Lixus obesus Petri, 1904 completes its generation in seed capsules of Prangos uloptera DC. This is regarded a new ecological niche for the genus Lixus, which is known to be stem-boring. Gültekin (2006) also documented the oviposition behavior of Lixus nordmanni Hochhuth. However, the biology of most species of this genus is poorly investigated. This paper aims to elucidate on one of the most important parts of their life cycle, ovipositing.

\section{Materials and methods}

Investigations were conducted in the provinces of Adıyaman, Artvin, Bayburt, Elazığ, Erzincan, Erzurum, Gümüşhane, Iğdır, Kars, Kayseri, Malatya, Nevşehir, Niğde, and Trabzon in the eastern part of Anatolia. Several expeditions were conducted to describe the biodiversity of Lixini (Coleoptera: Curculionidae; Lixinae) from 1997 to 2005 . The area includes extensive agricultural land and natural habitats, with altitudes ranging from 50 to $2,400 \mathrm{~m}$. The climate is cold and snowy during winter; it is warm and dry during summer.

The main goal was to investigate the biodiversity of Lixini tribe, describe host plant linkages, and determine its ecological niche in eastern Anatolia. In studying weevil and host association, oviposition marks were located and places where eggs were laid were observed by opening the plant stems and other plant organs. These observations were done in the natural habitats of weevils and associated host plants. The oviposition behavior of some species was likewise observed in the field.

\section{Results}

All the Lixus species studied had early activity compared with other species from Lixinae, especially Larinus Dejean. Generally, male individuals associated with their host plants in the early spring before the females. Most adult species fed on leaves of plants, even if the species have special feeding characteristics. For instance, $L . s u b$ tilis, L. bardanae, L. filiformis, $L$. cardui, and $L$. $k o r b i$ fed on leaves, opening several small round holes. Lixus nordmanni and L. ochraceus fed on the outer margin leaves, making wide semi-circular holes. Lixus circumcinctus fed on Crambe orientalis L. and Crambe tataria Sebeok, chewing directly on the stem, bud, or petiole. Secondary adult food sources of Lixus are plant stems and petioles upon opening excavations for eggs. Apparently, overwintered adults need to feed for some period before mating and ovipositing.

Before laying eggs, the females mated several times with the males. Some species even continued mating during oviposition (L. cardui, L. filiformis). Furthermore, some male species preferred to mate while the females were opening oviposition holes (L. furcatus) or inserting eggs in the oviposition cavity ( $L$.sp. n. pr. korbi). The females did not try to escape or show antagonistic behavior against the male during this time. Furthermore, they continued opening the cavity and pushing the egg into the hole. The rostrum is a unique organ used to make oviposition holes instead of the ovipositor, one of the main organs to be captured of female pronotum or on the scu- 


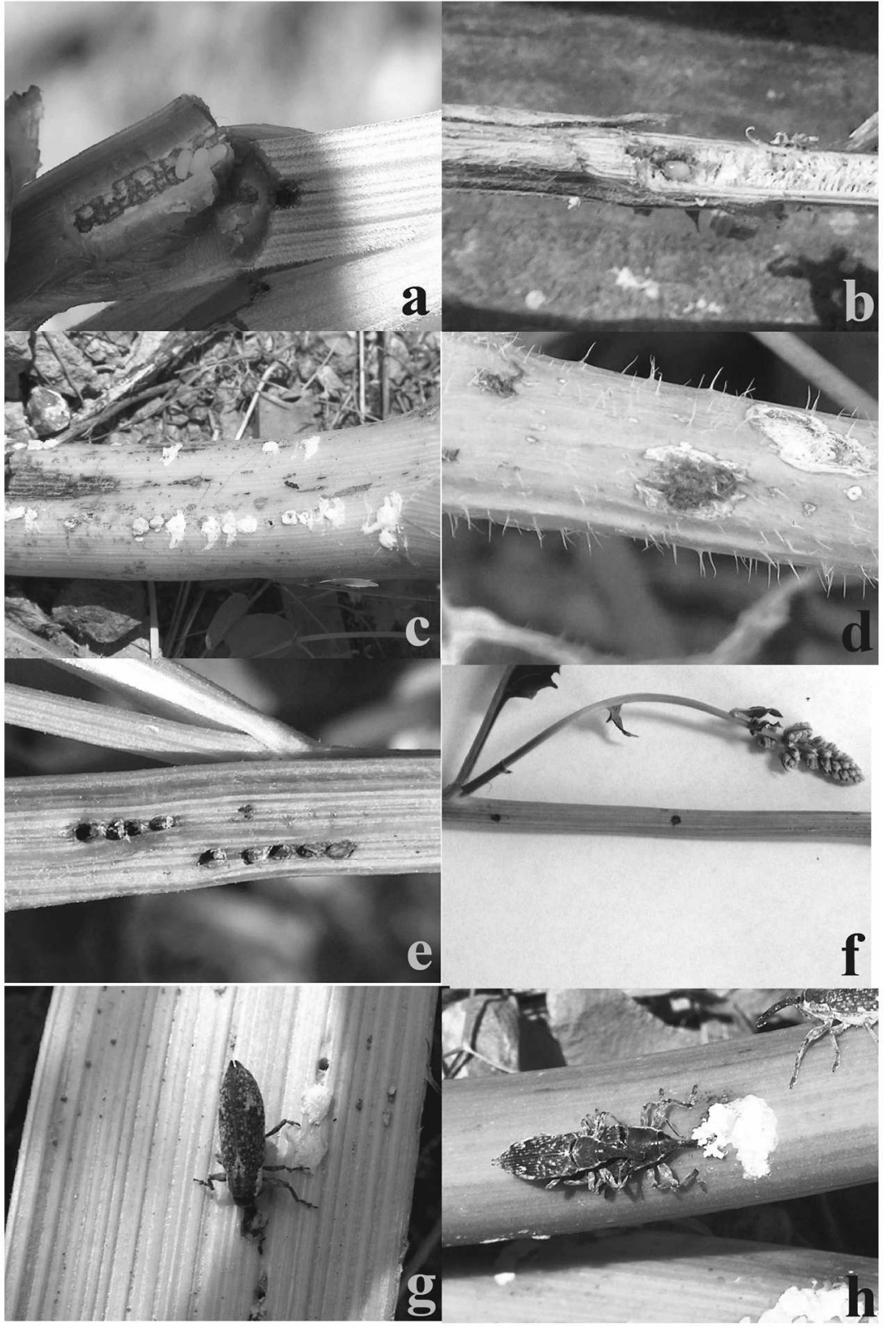

Fig. 1. Eggs and oviposition marks of Lixus F. genus. - a. Lixus nordmanni Hochhuth (eggs). - b. Lixus scolopax Boheman (egg). Oviposition marks. - c. Lixus furcatus Olivier. - d. Lixus circumcinctus Boheman. e. Lixus sp. n. pr. korbi Petri; and -f. Lixus korbi Petri. Excavating oviposition holes by female. - g. Lixus sp. $\mathrm{n}$. pr. furcatus Olivier and h. Lixus furcatus Olivier (and mating position). tellar area by the male at the mating position.

In preparing to excavate, the ovipositing female moved in such a way that forelegs were positioned anterolaterally and the hind legs posterolaterally, and all tarsi held the stem or petiole, sometimes with legs embracing the stem in form of a ring if the plant stem is thin enough. The female ( $L$. sp. n. pr. korbi) started to remove the epidermal tissue of the stem or petiole, biting off small pieces of plant tissue. The rostrum was moved toward the inside of the hole. From time to time, the female removed the rostrum from the hole. The rostrum was completely inserted into the hole when drilling of the hole is almost finished. Upon completion, the female walked away slowly and tried to position the tip of the abdomen in the cavity. Staying in this position without any movement, only the abdomen extended and retracted several times, with the rostrum touching the plant tissue and helping keep the female mo- 
Fig. 2. Matrix of oviposition niches of the Lixus F. in eastern Turkey.

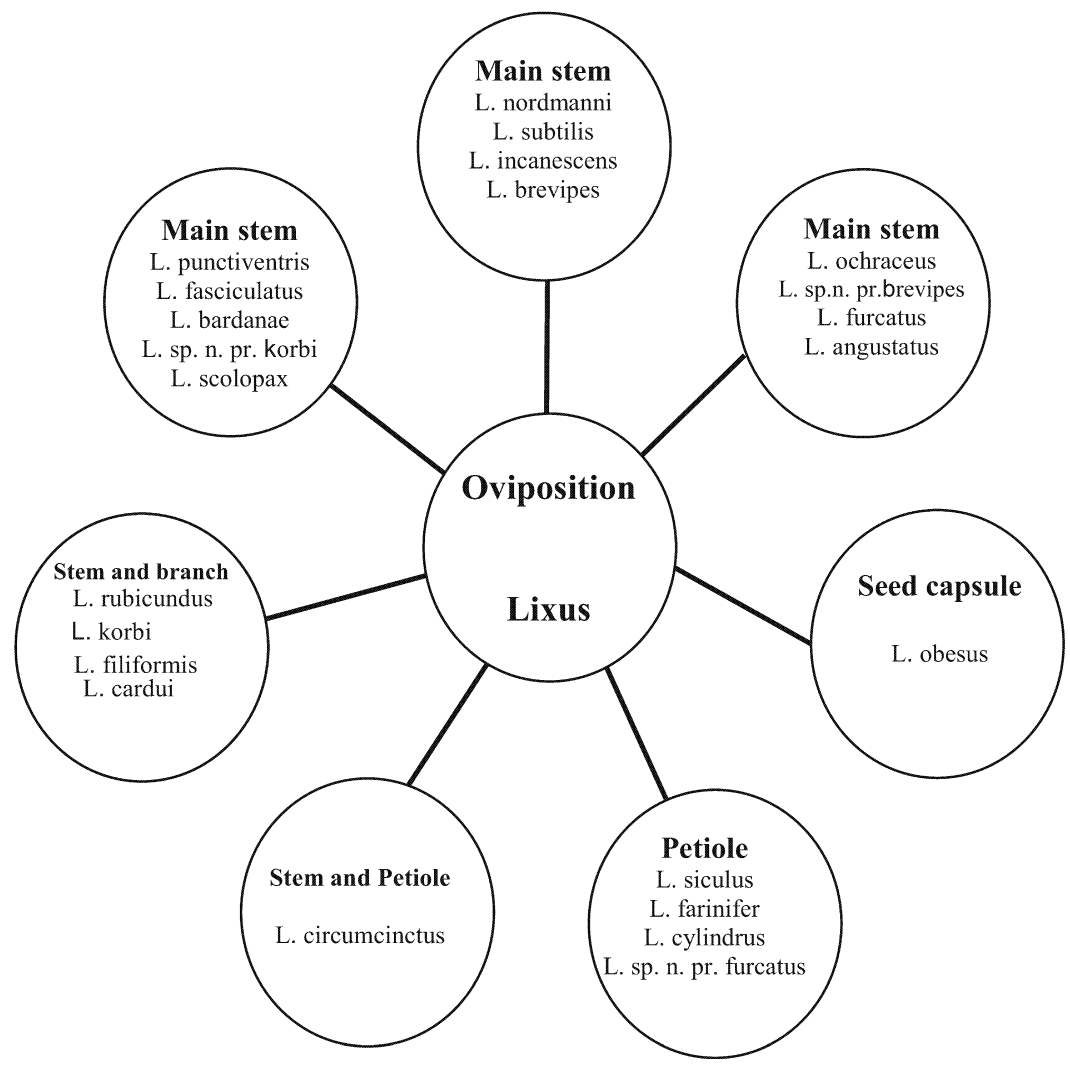

tionless. After eggs were laid in the hole, the female used the rostrum to push eggs in the bottom of the oviposition hole.

Cavities and oviposition marks have some distinct characteristics, depending on weevil species, rostrum length, and plant tissue. Both interspecific and intraspecific peculiarities among species exist starting from the aspect of site selection for laying eggs. Lixus nordmanni laid creamy white eggs solitarily or 2-3 eggs together in the same oviposition hole (Fig. 1a). Lixus bardanae and L. punctiventris laid yellowish ellipsoid eggs in hollow parts solitarily. The eggs of both of species were observed from the base to the tip of the plant stem, 5-9 cm apart from each other. Lixus subtilis, L. incanescens, and L. rubicundus laid yellowish, nearly rounded eggs one at a time in the main stem of their host plants, 4-5 $\mathrm{cm}$ from the base of the stem. Lixus brevipes and $L$. sp. n. pr. brevipes deposited yellowish eggs in the hollow part of the main stem. Even if eggs, 4 5 eggs in one stem, of $L$. brevipes occur along the stem, $L$. sp. n. pr. brevipes eggs, usually one egg in one stem, inspected only the little upper of root crown of plant. Lixus ochraceus deposited eggs, one by one, into the stem, opening cavities in the plant tissue. Eggs were abundant along the median parts, usually 7-8 eggs were placed in one stem; at times, this number reached 11-12. Lixus fasciculatus oviposited in the main stem; usually 1 or 2 eggs can be found in one stem in the upper part of the plant. Lixus filiformis and L. cardui deposited yellowish green eggs, one by one, or very near each other solitarily from the base to the tip of the stem, including the lateral branch of the plant. Lixus angustatus preferred to lay solitary yellowish eggs, approximately in the upper $15 \mathrm{~cm}$ of the stem up to the tip. Lixus korbi laid yellowish green eggs in the hollow part of the main stem and in the thick lateral branches, solitarily at 7-8 cm distance (Fig. 1f), but L. sp. n. pr. korbi eggs touched each other in groups of 4-5 (Fig. 1e). Both these species protected the eggs by a secretion that hardened and turned brownish black in time. While L. furcatus oviposited in the main stem of their host plants (Fig. 1h), L. sp. n. pr. 
furcatus (Fig. 1g), L. farinifer, L. cylindrus and $L$. siculus laid eggs on the plant petioles only. Lixus furcatus, including four petiole borers, deposited eggs solitarily, closed the holes with a secretion mixed with thin plant fibril remnant. Pale brownish oviposition marks can be seen easily on the plant (Fig. 1c). On the other hand, these plants strongly respond to excavation damage by secreting a resin-like liquid that sometimes closed the oviposition holes too. Lixus scolopax laid eggs one by one (Fig. 1b) and closed holes with a thick layer of secretion. These brownish black oviposition marks were seen easily. The female of L. circumcinctus laid eggs on the stem and petiole of leaves, opening the cavity with the rostrum. Then, the surface of the eggs and their surroundings were covered by a secretion prepared by chewing plant fibers while opening the cavity. These places turned purplish brown-black in the course of time (Fig. 1d). Each plant has 1-21 eggs, depending on plant size and number of adults.

\section{Discussion}

The use of the rostrum for excavating an oviposition site in a plant structure can be seen clearly as a key point in explaining the diversity within superfamily Curculionoidea (Zwölfer 1975). Subfamily Lixinae, one of the richest groups in family of Curculionidae and in this present study, Lixus oviposition takes place in live plant tissue using the rostrum for excavating oviposition places. This paper found that most Lixus species laid eggs usually in the stems of plants; 13 species in main stem, four species stem and lateral branches, a species stem and petiole (Fig. 2; Table 1). However, only some Callistolixus Reitter (L. farinifer, L. cylindrus, and $L$. sp. n. furcatus) and the Eulixus Reitter (Lixus siculus) species laid eggs in the petioles of their host plants. Furthermore, larval and pupal growth occurred in these ecological niches. In addition, these four Callistolixus species and L. circumcinctus, $L$. scolopax, $L$. korbi and $L$. sp. n. pr. korbi applied a greater amount of secretion to close the oviposition holes. This peculiarity gives greater egg protection and avoids predation, parasitism, and desiccation.
Anderson (1995) suggested that the development of a longer rostrum by the female species of Curculionoidea allowed the invasion of a new adaptive zone through excavation of oviposition sites in plant parts, which are otherwise not previously available as food sources for immature stages. The most interesting example shown by Gültekin (2005) is L. obesus, which had the unique behavior of laying eggs in the seed capsule of Prangos uloptera, in contrast to the general biological records of the genus Lixus.

Studying the different species of endophagous stem borers on thistles, Zwölfer \& Brandl (1989) showed niche portioning according to body size. Hence, two or even three different species coexist in different parts of the stem of the same host plant. Selection of different plant organs on which to lay eggs in may avoid interspecific competition between species. According to the present data set, Prangos plant stems were used by L. furcatus in immature biological stages and $P$. uloptera was one of the host plants of $L$. furcatus in eastern Anatolia. However, L. obesus has the same plant host. Apparently, this weevil may have jumped to the seed capsule to avoid interspecific competition with each other.

In all species studied, only one egg is laid per cavity, except for L. nordmanni, which occasionally laid three eggs in one hole. Common European species Lixus iridis Olivier, 1807 laid eggs in hollow parts of stem of the Anthriscus nemorosa (Bieb.) Spreng (Volovnik 1994) which is not found in eastern part of Turkey. In this region, $L$. nordmanni is widespread on several Apiaceae (Gültekin 2006).

The selection of the petiole as oviposition site by four Lixus species (L. siculus, L. farinifer, $L$. cylindrus, and $L$. sp. n. pr.furcatus) reflects a new ecological niche where both oviposition and growth of immature stages take place. This may be possible, depending on the structure of main stem tissue, asynchronous vegetation, and lack of competition with other species. For instance, the host plant of $L$. farinifer has only leaves in the beginning of summer; the stem shows up in late summer when the oviposition period of the weevil has already passed. The main stem and lateral branch of the host plant of $L$. siculus is an extremely hard tissue. Thus, the softer petiole is preferred for oviposition and growing of larvae. 
Table 1. Oviposition niches of the Lixus F. in eastern Turkey.

\begin{tabular}{|c|c|c|c|}
\hline Weevil species & Host plants & Niches of eggs & References \\
\hline Lixus nordmanni Hochhuth & $\begin{array}{l}\text { Heracleum trachyloma } \\
\text { Fisch. et Mey. } \\
\text { H. sosnowskyi Manden } \\
\text { H. pastinacifolium C. Koch } \\
\text { H. platytaenium Boiss. } \\
\text { Angelica sylvestris L. } \\
\text { Pastinaca urens Req. et Godr. }\end{array}$ & Main stem & Gültekin 2006 \\
\hline Lixus subtilis Boheman & Chenopodium vulvaria L. & Main stem & \\
\hline Lixus incanescens Boheman & $\begin{array}{l}\text { Salsola kali } \mathrm{L} \text {. } \\
\text { Chenopodium foliosum Asch. } \\
\text { C. vulvaria } \\
\text { Beta vulgaris } \mathrm{L} \text {. }\end{array}$ & Main stem & \\
\hline Lixus brevipes Brisout & Gypsophila sp. & Main stem & \\
\hline Lixus sp. n. pr. brevipes Brisout & Silene vulgaris (Moench) Garcke & Main stem & \\
\hline Lixus ochraceus Boheman & Tchihatchewia isatidea Boiss. & Main stem & Korot. \& Gült. 2003 \\
\hline Lixus furcatus Olivier & $\begin{array}{l}\text { Prangos uloptera } \\
\text { P. ferulacea } \\
\text { P. lophoptera Boiss. }\end{array}$ & Main stem & \\
\hline Lixus angustatus (Fabricius) & Cirsium sp. & Main stem & \\
\hline Lixus punctiventris Boheman & Senecio sp. & Main stem & \\
\hline Lixus fasciculatus Boheman & Artemisia vulgaris & Main stem & \\
\hline Lixus bardanae (Fabricius) & $\begin{array}{l}\text { Rumex crispus L. } \\
\text { R. patientia L. }\end{array}$ & Main stem & Gültekin et al. 2004 \\
\hline Lixus sp. n. pr. korbi Petri & Beta trigyna & Main stem & \\
\hline Lixus scolopax Boheman & $\begin{array}{l}\text { Echinops sphaerocephalus L. } \\
\text { Centaurea solstitialis L. } \\
\text { Centaurea sp. }\end{array}$ & Main stem & \\
\hline Lixus rubicundus Zoubkoff & $\begin{array}{l}\text { Kochia prostrate (L.) Schrad. } \\
\text { Chenopodium sp. }\end{array}$ & Stem and branch & \\
\hline Lixus korbi Petri & $\begin{array}{l}\text { Beta corolliflora Zoss. } \\
\text { B. trigyna Waldst. et Kit. }\end{array}$ & Stem and branch & \\
\hline Lixus filiformis (Fabricius) & $\begin{array}{l}\text { Carduus nutans L. } \\
\text { C. crispus L. }\end{array}$ & Stem and branch & Gültekin 2004 \\
\hline Lixus cardui Olivier & Onopordum bracteatum & Stem and branch & Gültekin et al. 2000 \\
\hline Lixus circumcinctus Boheman & $\begin{array}{l}\text { Crambe orientalis L. } \\
\text { C. tataria Sebeok }\end{array}$ & Stem and petiole & \\
\hline Lixus siculus Boheman & Ferula orientalis L. & Petiole & \\
\hline Lixus farinifer Reitter & Ferula szowitsiana DC. & Petiole & \\
\hline Lixus cylindrus (Fabricus) & Prangos ferulacea (L.) Lindl. & Petiole & \\
\hline Lixus sp. n. pr. furcatus Olivier & Prangos sp. & Petiole & \\
\hline Lixus obesus Petri & Prangos uloptera DC. & Seed capsule & Gültekin 2005 \\
\hline
\end{tabular}

Twenty-three Lixus species used plants from six different plant families as host plant and oviposition sites; 14 Apiaceae, 11 Compositae, 8 Chenopodiaceae, 4 Brassicaceae, 2 Polygonaceae, and 2 Caryophyllaceae species were used. The highest number of Lixus species is associated with plant families Apiaceae (7), Compositae (6), and Chenopodiaceae (6) (Table 1). Of these plants, $C$. nutans, $O$. bracteatum, $C$. solstitialis, and $R$. crispus, are important weeds in the region
(Gültekin et al. 2000, 2004, Gültekin 2004, Cristofaro et al. 2002).

Associations of host plants with Lixus at the subgeneric level show an overlap with different plant families in some subgenera. The subgenus Eulixus used Apiaceae, Caryophyllaceae, Chenopodiaceae, Brassicaceae; Dilixellus Reitter used Chenopodiaceae, Compositae, and Polygonaceae. Some subgenera deal with host plant groups as a tribe or a family level in this study 
area-Epimeces Billberg used only Cardueae tribe (Compositae); Callistolixus used only Apiaceae; Compsolixus Reitter and Lixogylptus Reitter used only Brassicaceae.

The species Prangos Lindl., Ferula L. and Tchihatchewia isatidea Boiss. can be important bio-indicators of the degree of erosion. T. isatidea grows in the peculiar conditions of steep, dry detritus or clay slopes in the northeastern Anatolian mountains, this highly moveable substrate, though providing easy access to water is subjected to erosion and abrasion and holds the characteristic vegetation of a few species of Brassicaceae (Korotyaev \& Gültekin 2003). Prangos and Ferula species grow under similar characteristic conditions of dry detritus or clay slopes in the high afforested mountains in eastern Anatolia, also subjected to erosion and abrasion where apparently, these plants can be highly important plant groups in avoiding the negative effect of erosion and abrasion.

Differences in oviposition places and marks can help distinguish related species in the field. Also, these ecological characteristics can help differentiate near species. For instance, $L$. furcatus and $L$. sp. n. pr. furcatus are sibling species. It is not easy to distinguish these two species taxonomically, except for the apical part of aedeagus. On the other hand, ecological niches of immature stages are clearly different as indicated above. Lixus korbi and L. sp. n. pr. korbi are closely related species, but their oviposition behaviors are different. The latter lays eggs connected to each other (Fig. 1e), the former lays eggs clearly distant from each other (Fig. 1f). Consequently, these behavioral traits can serve to reflect taxonomic characters and thereby clarify relationships between species. The data could be useful as a systematic tool, but more so in understanding these behaviors in the ecological context.

Acknowledgements. I am grateful to Dr. Vladimir I. Dorofeyev (Botanical Institute, Russian Academy of Sciences, St. Petersburg) and Professor Hüseyin Zengin (Atatürk University, Erzurum, Turkey) for their help in plant identification. I sincerely thank Dr. Boris A. Korotyaev (Zoological Institute, Russian Academy of Sciences, St. Petersburg, Russia) for his valuable contributions on the taxonomical position of the species. The study was supported by CLG- 978845 and NR-CLG-981318 of the NATO Life
Science and Technology Programme, and by two grants from the European Commission's (FP 6) Integrated Infrastructure Initiative programme SYNTHESYS (DK-TAF and SE-TAF).

\section{References}

Anderson, R. S. 1995: An evolutionary perspective on diversity in Curculionoidea. - Memoirs Entomol. Soc. Wash. 14: 103-114.

Briese, D. T. 1996: Potential impact of the stem-boring weevil Lixus cardui on the growth and reproductive capacity of Onopordum thistle. - Biocont. Sci. and Tech. 6: 251-261.

Cristofaro, M., Hayat, R., Gültekin, L., Tozlu, G., Zengin, H., Tronci, C., Lecce, F., Șahin, F. \& Smith, L. 2002: Preliminary screening of new natural enemies of yellow starthistle, Centaurea solstitialis L. (Asteraceae) in Eastern Anatolia. - Proceedings of the Fifth Turkish Biological Control Congress, 4-7 September, Erzurum: 287-295.

Csiki, E. 1934: Curculionidae: subfam. Cleoninae. - In: Coleopterorum Catalogus W. Junk-S. Schenkling, 134: 1-152. Berlin.

Eber, S., Knoll, S. \& Brandl, R. 1999: Endophagous insects and structural niches on plants: ecology and evolutionary consequences. - Ecol. Entomol. 24: 292 299.

Freese, G. 1994: Insect complexes associated with the stems of seven thistle species. - Entomol. Gen. 19(3): 191-207.

Gültekin, L. 2004: Weevils associated with Musk thistle (Carduus nutans L.) and biology of Lixus filiformis (Fabricius) (Coleoptera, Curculionidae) in Northeastern Turkey. - J. Entomol. Res. Soc. 6(3): 1-8.

Gültekin, L. 2005: New ecological niche for weevils of the genus Lixus Fabricius and biology of Lixus obesus Petri (Coleoptera: Curculionidae, Lixinae). - Weevil News No. 24. 3 p., $10^{\text {th }}$ January 2005 [www document] URL: http://www.curci.de/Inhalt.html.

Gültekin, L. 2006: Host plant range and biology of Lixus nordmanni Hochhuth (Coleoptera, Curculionidae) on hogweed Heracleum L. in eastern Turkey. _ J. Pest Sci. 79: 23-25.

Gültekin, L., Güçlü, Ș. \& Özbek, H. 2000: The biology of Larinus latus (Herbst) and Lixus cardui (Olivier) (Coleoptera, Curculionidae) on Onopordum bracteatum Boiss. et Heldr. (Asteraceae). — Proceedings of the Fourth Turkish National Congress of Entomology, 12-15 September 2000, Kuşadası-Aydın: 197-206. [In Turkish]

Gültekin, L. Zengin, H. \& Hayat, R. 2004: Life History of Lixus bardanae on Curly Dock (Rumex crispus) in Turkey. — Phytoparasitica 32 (1): 97-99.

Julien, M. H., Kassulke, R. C. \& Harley, K. L. S. 1984: Lixus cribricollis (Col.: Curculionidae) for biological control of weeds Emex spp. and Rumex crispus in Australia. — Entomophaga 27(4): 439-446. 
Korotyaev, B. A. \& Gültekin, L. 2003: Biology of two weevil, Lixus ochraceus Boheman and Melanobaris gloriae sp. n. (Insecta: Coleoptera, Curculionidae), associated with Tchihatchewia isatidea Boissier, a cruciferous plant endemic of Turkey. - Entomol. Abh. 61(1): 93-99.

Nikulina, O. N. 1989: Biology of weevils of the genus Lixus (Coleoptera, Curculionidae) developing in semishrub and herbaceous plants in Tajikistan. - Entomologischeskoye Obozreniye 3: 511-521. [In Russian]

O’Brien, C. W. \& Wibmer, G. J. 1978: Number of genera and species of Curculionidae (Coleoptera). - Entomol. News 89: 89-92.

Petri, K. 1904/1905: Bestimmungs-Tabellen der europäischen Coleopteren. - 55. Curculionoidea, Lixus F.: 1-62. Paskau.

Şengonca, Ç. 1981: Investigations on the safflower pest Lixus speciosus Mill. (Col.: Curculionidae) in the $\mathrm{Cu}$ kurova plain of South Anatolia. - Rijksuniversiteit Gent 46(2): 623-628.

Sobhian, R., Tunç, I. \& Erler, F. 1999: Preliminary studies on the biology and host specificity of Aceria salsolae DeLillo and Sobhian (Acari, Eriophyidae) and Lixus salsolae Becker (Col., Curculionidae), two candidates for biological control of Salsola kali. - J. Appl. Entomol. 123(4): 205-209.
Ter-Minassian, M. E. 1967: Zhuki-dolgonosiki podsemejstva Cleoninae fauny SSSR. Tsvetozhily i stebleedy (triba Lixini). — Nauka, Leningrad, 1-140. [In Russian]

Volovnik, S. V. 1988: A stem-feeding weevil as a pest of hogweed. - Zashchita Rastenii Moskva 12: 31. [In Russian]

Volovnik, S. V. 1994: On the oviposition of weevils of the genus Lixus (Coleoptera, Curculionidae). - Entomol. Rev. 74(7): 115-120.

Yıldırım, E. \& Özbek, H. 1992: Insect fauna of sugar beet in sugar beet growing areas of Erzurum Sugar Factory. - Proceedings of the Second Turkish National Congress of Entomology, 28-31 January, Adana, 621635. [In Turkish]

Zwölfer, H. 1975: Rüsselkäfer und ihre Umwelt - ein Kapitel Ökologie. — Stuttgard Beiträge zur Naturkunde 3: 19-31.

Zwölfer, H. \& Harris, P. 1984: Biology and host specificity of Rhinocyllus conicus (Froel.) (Col., Curculionidae), a successful agent for biocontrol of the thistle, Carduus nutans L. - J. Appl. Entomol. 97: 36-62.

Zwölfer, H. \& Brandl, R. 1989: Niches and size relationships in Coleoptera associated with Cardueae host plants: adaptations to resource gradients. - Oecologia 78: $60-68$. 